\title{
DIREITOS POLÍTICOS DE ESTRANGEIROS RESIDENTES NO BRASIL: CRÍTICA DOS PROJETOS LEGISLATIVOS NO CONTEXTO MIGRATÓRIO DA AMÉRICA LATINA
}

\author{
POLITICAL RIGHTS OF FOREIGN RESIDENTS IN BRAZIL: \\ CRITICISM OF LEGISLATIVE PROJECTS IN THE MIGRATORY CONTEXT OF \\ LATIN AMERICA
}

\section{DERECHOS POLÍTICOS DE EXTRANJEROS RESIDENTES EN BRASIL: CRÍTICA DE LOS PROYECTOS LEGISLATIVOS EN EL CONTEXTO MIGRATORIO DE AMÉRICA LATINA}

\author{
LUIZ ISMAEL PEREIRA \\ http://orcid.org/0000-0001-7560-4579 / http://lattes.cnpq.br/7398144875342498 / luiz.ismael@gmail.com \\ Universidade Federal de Viçosa \\ Viçosa, Minas Gerais, Brasil \\ CAMILO ONODA CALDAS \\ http://orcid.org/0000-0003-0591-9473 / http://lattes.cnpq.br/6584473320284037 / camilo.onoda@gmail.com \\ Universidade São Judas Tadeu \\ São Paulo, São Paulo, Brasil.
}

\begin{abstract}
RESUMO
O presente artigo tem como objetivo geral analisar as recentes Propostas de Emenda Constitucional (PEC's) brasileiras voltadas a ampliar os direitos políticos dos estrangeiros residentes no Brasil. Parte-se das categorias tradicionais da Teoria Geral do Estado e da Ciência Política, bem como os fluxos migratórios de países da América Latina em direção ao território brasileiro, a partir de 1980, dentro de um contexto de transformação econômica - transição do regime de acumulação fordista para pós-fordista - e de marginalização de grupos sociais, dentre eles os imigrantes. 0 problema de pesquisa está relacionado à possibilidade e forma de concessão de voto ao estrangeiro no país. 0 tema é relevante devido ao aumento do fluxo migratório para o país, em especial de refugiados, analisado a partir de uma teoria materialista do Estado. Percebe-se que, com a redemocratização, diversas PEC's apresentadas com a finalidade de ampliar os direitos políticos de estrangeiros em território brasileiro, algumas, ainda, em tramitação. Conclui-se que há diversas divergências com um potencial de avanço em relação aos direitos políticos do estrangeiro no Brasil, embora haja entraves políticos.
\end{abstract}

Palavras-chave: América Latina; Direitos fundamentais; Estrangeiros no Brasil; Imigração; Sufrágio.

\section{ABSTRACT}

The main objective of this article is to analyze the recent proposals of the Brazilian Legislative Power (PEC's) aimed at broadening the political rights of foreign residents in Brazil. The starting point of the study are the traditional categories of the General Theory of State and Political Science, as well as the migratory flows of Latin American countries towards the Brazilian territory in the last decades (after creation of the Foreigners Statute, Federal Law 6,815 / 1980) within a context of economic transformation - a transition from Fordist accumulation to post-Fordist and from the marginalization of social groups, among them the immigrants group. The research problem is related to the possibility and way of granting the foreign vote in the country. The theme is relevant for the increase in the migratory flow to the country, especially refugees, analyzed from a materialist theory of the State. We can see several PECs presented with the purpose of expanding the political rights of foreigners in Brazilian territory, some still in process after with re-democratization period. It is concluded that the proposals differ in several respects with a potential for advancement in relation to the political rights of the foreigner in Brazil, although there are political obstacles.

Keywords: Foreigners in Brazil; Fundamental rights; Immigration; Latin America; Suffrage. 


\section{RESUMEN}

El presente artículo tiene como objetivo general analizar las recientes Propuestas de Enmienda Constitucional (PEC) brasileñas orientadas a ampliar los derechos políticos de los extranjeros residentes en Brasil y, para ello, analiza diversos aspectos de ese conjunto de propuestas. Se parte de las categorías tradicionales de la Teoría General del Estado y de la Ciencia Política, así como los flujos migratorios de países de América Latina hacia el territorio brasileño, a partir de 1980, dentro de un contexto de transformación económica - transición del régimen de acumulación fordista para post-fordista - y de marginación de grupos sociales, entre ellos los inmigrantes. El problema de investigación está relacionado con la posibilidad y forma de concesión de voto al extranjero en el país. El tema es relevante debido al aumento del flujo migratorio hacia el país, en especial de refugiados, analizado a partir de una teoría materialista del Estado. Se percibe que, con la redemocratización, diversas PEC's presentadas con la finalidad de ampliar los derechos políticos de extranjeros en territorio brasileño, algunas, aún, en tramitación. Se concluye que hay varias divergencias con un potencial de avance en relación a los derechos políticos del extranjero en Brasil, aunque hay obstáculos políticos.

Palabras clave: Derechos fundamentales; Extranjeros en Brasil; Inmigración; Latinoamerica; Sufragio.

\section{SUMÁRIO}

INTRODUÇAO; 1 CONSTITUIÇÃO DO ESTADO-NAÇÃO E DESENVOLVIMENTO ECONÔMICO NACIONAL: 0 TRABALHADOR IMIGRANTE NO REGIME DE ACUMULAÇÃO PÓS-FORDISTA; 2 DIREITO AO VOTO DE ESTRANGEIROS: PANORAMA NA AMÉRICA LATINA E DO BRASIL; 3 VOTO DE ESTRANGEIROS RESIDENTES NO BRASIL: PROPOSTAS DE EMENDA CONSTITUCIONAL VISANDO AMPLIAÇÃO DE DIREITOS POLÍTICOS; CONCLUSÃO; REFERÊNCIAS.

\section{INTRODUÇÃO}

O Brasil é um país cuja população constitui-se historicamente a partir do fluxo de estrangeiros. O território nacional foi colonizado pelos portugueses a partir do século XVI. As diversas populações indígenas que já habitavam o local passaram a conviver com os colonizadores e posteriormente com contingentes populacionais de origem diversificada, mobilizados por razões diversas: imigração voluntária da Europa e Ásia (especialmente Japão), migração forçada de povos da África por conta da escravidão. Mais recentemente, tem sido crescente a imigração oriunda da própria América Latina, neste caso, tais imigrantes ainda permanecem no Brasil, em sua maioria, como estrangeiros.

Alguns dados são significativos: o Brasil abriga 1.847.274 imigrantes regulares, segundo estatísticas da Polícia Federal atualizadas em março de 2015. ${ }^{1}$ Entre 2010 e 2015, registrou-se um aumento de $131 \%$ no número de trabalhadores imigrantes integrados ao mercado de trabalho formal brasileiro (de 54.333 para 125.535), um aumento expressivo, mesmo assim os estrangeiros ainda compõe apenas uma pequena fração do total dos trabalhadores nesta

1 ARANTES, José Tadeu. Imigrantes: as brechas para o acolhimento. Disponível em: http://agencia.fapesp.br/imigrantes_as_brechas_para_o_acolhimento/21466/. Acesso em: 09 abr. 2017. 
condição $(0,5 \% \text { da força de trabalho total do Brasil })^{2}$. No mesmo período, as solicitações de refúgio cresceram 2.868\% (de 966 para 28.670) ${ }^{3}$. Conforme notícia veiculada com base nas estatísticas da Polícia Federal, o número de estrangeiro registrados por ano teria aumentado 160\% de 2006 para 2016 (de 45.124 para 117.745, com predomínio, em número absolutos, de haitianos, bolivianos, colombianos e argentinos) ${ }^{4}$. Tais dados não abrangem os imigrantes que se encontram em situação considerada "irregular", ou indocumentada, pois inexistem dados fidedignos a esse respeito, ainda que a existência deste contingente seja reconhecida.

O impacto desses movimentos de imigração, sobretudo nos grandes centros urbanos, tem despertado interesse crescente das instituições de Estado, da imprensa, da academia e da sociedade civil em geral. Tal questão se torna especialmente relevante quando se nota que todos indicadores evidenciam um crescimento desse movimento populacional.

Conforme mencionaremos mais adiante, os fluxos de imigração da atualidade seguem uma lógica distinta daqueles ocorridos no período que um regime fordista de acumulação se desenvolvia. No Brasil, originalmente, os grandes movimentos de imigração foram resultado de uma política Estado, especialmente no período posterior a abolição da escravidão e industrialização do país, na passagem do final do século XIX para o século XX. Na atualidade, os novos movimentos de imigração se desenvolvem dentro de um regime de acumulação pósfordista, no qual o modo de regulação segue um padrão distinto, no qual as condições de trabalho se precarizam e as tradicionais garantias do trabalhador enfraquecem ou desaparecem, levando a marginalização de grupos sociais, dentre eles os estrangeiros, estejam ou não sem situação juridicamente regular no país.

O preconceito e a discriminação reforçam, ainda, o processo de marginalização econômico e jurídico. Portanto um duplo processo, dentro e fora da legalidade, impede e dificulta o processo de integração do estrangeiro no Brasil. Nesse contexto, políticas públicas específicas para a questão dos estrangeiros residentes no território brasileiro se fazem necessárias. Contudo, tais iniciativas dependem em grande medida da existência de mecanismos

2 PORTAL BRASIL. Número de trabalhadores imigrantes no País cresceu 131\%. Disponível em: http:// www.brasil.gov.br/economia-e-emprego/2016/12/numero-de-trabalhadores-imigrantes-no-paiscresceu-131. Acesso em: 09 abr. 2017.

${ }^{3}$ MINISTÉRIO DA JUSTIÇA. Brasil tem quase 9 mil refugiados de 79 nacionalidades. Disponível em: http://www.justica.gov.br/noticias/brasil-tem-quase-9-mil-refugiados-de-79-nacionalidades-1. Acesso em: 09 abr. 2017.

${ }^{4}$ VELASCO, Clara; MANTOVANI, Flávia. Em 10 anos, número de imigrantes aumenta $160 \%$ no Brasil, diz PF: Só em 2015, quase 120 mil estrangeiros deram entrada no país. Haitianos lideram o ranking atual, seguidos pelos bolivianos. Disponível em: http://g1.globo.com/mundo/noticia/2016/06/em-10-anosnumero-de-imigrantes-aumenta-160-no-brasil-diz-pf.html. Acesso em 06 abr. 2017. 
jurídicos e institucionais para garantir a participação e integração política de estrangeiros que residem no Brasil.

A extensão dos direitos políticos aos estrangeiros residentes no país é um dos pontos de partida fundamentais para promover o processo de integração política e social destes grupos aos demais existentes no território nacional, portanto, surge como questão problemática da presente pesquisa. 0 direito de votar e ser votado nas esferas nacionais (federal, estadual, municipal e distrital) e nos poderes constituídos por representantes políticos (Executivo e Legislativo) consiste em um direito fundamental e é também um mecanismo que pode estimular o desenvolvimento de políticas públicas voltadas a evitar que a marginalização e segregação econômico-social de estrangeiros permaneça ou cresça no país. Ainda que o direito ao voto entendido como direito de votar e ser votado - não seja o único direito político que possa ser estabelecido, não há dúvida que é de extrema relevância, pois se trata de um dos direitos mais fundamentais no campo político (CF/88, art. $1^{\circ}$, parágrafo único; e 14, caput).

A partir do contexto acima descrito e de uma análise das categorias tradicionais da Teoria Geral do Estado e da Ciência Política - e.g. Estado, Nação, Cidadania ${ }^{5}$ - examina-se quais os projetos legislativos existentes no Brasil para estabelecer - de forma inédita - o direito de voto aos estrangeiros que residem no território brasileiro.

Para compreender a problemática da extensão dos direitos políticos aos estrangeiros no país, é necessário compreender, a partir do referencial teórico de uma teoria materialista do Estado, a relação entre os modos de regulação e regimes de acumulação que influenciam a atuação do Estado no século XX, isto é, o fordismo e o pós-fordismo. Especialmente o processo de transição do primeiro para o segundo, o qual marcará a relação do Estado com o estrangeiro.

\footnotetext{
${ }^{5} \mathrm{Na}$ visão de Camilo Caldas, "a cidadania implica em um vínculo permanente entre um indivíduo a um determinado Estado. Tal vinculação implica na permissão jurídica de que o cidadão influencie a formação e transformação do Estado, bem como na submissão à autoridade estatal, mesmo estando fora de seu território (nessa hipótese, como vimos, há eventual dificuldade para se efetivar tal controle). [...]Nação designa algo diferente de povo e de população. Neste caso, novamente, existem certas ambiguidades. 0 termo "nacionalidade" muitas vezes se confunde com "cidadania". É comum ouvir que alguém adquiriu outra "nacionalidade" se naturalizando como cidadão de outro país. No entanto, nação não é conjunto de cidadãos, pois, o vínculo que une indivíduos numa mesma nacionalidade não é jurídico, mas sim cultural. Uma nação possui uma unidade que pode se manifestar em vários aspectos: idioma, religião, costumes, alimentação, vestuário etc.”. CALDAS. Camilo Onoda. O Estado. São Paulo: Estúdio editores.com, 2014.
} 


\section{CONSTITUIÇÃO DO ESTADO-NAÇÃO E DESENVOLVIMENTO ECONÔMICO}

\section{NACIONAL: O TRABALHADOR IMIGRANTE NO REGIME DE ACUMULAÇÃO PÓS-FORDISTA}

Os Tratados de Münster e Osnabrück, que materializaram a chamada Paz de Vestfália, foram responsáveis pelo estabelecimento das características de respeito à soberania, território e população inerentes ao Estado-nação, persistentes até o século XXI, mas não sem tensões. $E$ tais tensões são intensificadas no processo de financeirização do mundo, de mundialização da economia, de generalização dos conflitos, aspectos inerentes à chamada globalização, um fator político, mas também econômico que forçará a revisão daqueles conceitos de direito internacional do séc. XVII.

O fator essencial para compreender como se dá essa interferência relativa do econômico no político, em especial na era da globalização, é a compreensão do tripé que sustenta a sociabilidade moderna: um econômico - o capitalismo, um político - o Estado, e, por fim, um jurídico - o direito. Esse tripé é responsável, não apenas pelo nível da circulação, ou mesmo da produção, mas também pela reprodução da sociabilidade ${ }^{6}$. Isso porque, como lembra John Holloway, o Estado não é uma coisa em si mesma, como quereria Hegel, mas uma relação social. Não se trata, de outro lado, de compreender que haja uma relação necessária entre vontade do capitalismo e atuação do Estado, como o estruturalismo defendeu. O Estado nacional deve ser compreendido na cristalização de relações entre pessoas que exercer uma coerção política e jurídica ${ }^{7}$.

\footnotetext{
6 "Assim, o processo capitalista de produção, considerado em seu conjunto ou como processo de reprodução, produz não apenas mercadorias, não apenas mais-valor, mas produz e reproduz a própria relação capitalista: de um lado, o capitalista, do outro, o trabalhador assalariado" (MARX, Karl. 0 capital. Livro 1. Tradução de Rubens Enderle. São Paulo, 2013, p. 653).

7 "The question then is not: how does the economic determine the political superstructure? Rather, it is: what is peculiar about the social relations of capitalism that gives rise to the rigidification (or particularisation) of social relations in the form of the state? The corollary of this is the question: what is it that gives rise to the constitution of the economic and the political as distinct moments of the same social relations? The answer is surely that there is something distinctive about the social antagonism on which capitalism (like any class society) is based. Under capitalism, social antagonism (the relation between classes) is based on a form of exploitation which takes place not openly but through the 'free' sale and purchase of labour power as a commodity on the market. This form of class relation presupposes a separation between the immediate process of exploitation, which is based on the 'freedom' of labour, and the process of maintaining order in an exploitative society, which implies the use of coercion" (HOLLOWAY, John. Global capital and the National State. Capital \& Class, NY, New York University, 1994, 18:23, p. 28. Disponível em: http://dx.doi.org/10.1177/030981689405200103. Acesso em 30 nov. 2018).
} 
A comunidade internacional é importante para a construção da dialética da produção de mais-valor dentro da esfera nacional. "Somente com a multiplicidade de Estados se estabelecem e se cimentam plenamente os mecanismos da reprodução do capital, porque", continua Alysson Mascaro, "a concorrência entre Estados dá unidade estrutural e ideológica ao acoplamento entre a exploração da força de trabalho e o interesse do capital nacional”8.

A soberania do Estado-Nação "não consiste no monopólio da coerção ou da dominação", ou seja, autonomia para exercer a jurisdição, a legislação e a gestão da coisa pública em seu território, "mas da decisão"9. Essa decisão política, inerente ao Estado-nação, seguirá os objetivos constituintes e auto constituídos. No sentido contrário, durante o século XX, em especial após a II Guerra Mundial, ficou claro à comunidade internacional que o desenvolvimento econômico, e mais tarde o humano e o social, tornaram-se a regra. Sem ele, o projeto de paz estabelecido na Carta de São Francisco nunca seria alcançado. Com esse mesmo propósito, as Organizações Econômicas Internacionais passam a estabelecer prazos, exigências e compromissos para garantir tal desenvolvimento.

As instituições de Bretton Woods (Fundo Monetário Internacional e Bando Mundial), Comissão Econômica para a América Latina e o Caribe (CEPAL), Comissão Econômica para a África - CEA, GATT etc., são exemplos de como a comunidade internacional passa a interferir na decisão de questões nacionais que levem os países ao desenvolvimento econômico, ou, numa melhor terminologia, à superação da dependência em relação ao mercado central. Será nesse sentido que Gilberto Bercovici apontará que a qualidade plena de expressão da soberania periférica - em seu caso, o exemplo brasileiro - encontra-se bloqueada, impedida de se expressar. Interesses internos e externos, do capital financeiro e do produtivo, impedem as decisões tomadas pelo Estado que deveria encontrar seu próprio caminho de independência econômica ${ }^{10}$.

O Estado-nação encontra no território seu espaço de atuação, de imposição de decisões, de exercício de sua soberania. A questão espacial será também alargada no processo de globalização das economias, seja como reação interna, para proteger os processos internos de

\footnotetext{
${ }^{8}$ MASCARO, Alysson Leandro. Estado e forma política. São Paulo, Boitempo, 2013, p. 97.

${ }^{9}$ BERCOVICI, Gilberto. 0 estado de exceção econômico e a periferia do capitalismo. Pensar, Fortaleza, v. 11, fev. 2006, p. 96.

10 "O problema central, ignorado pela maior parte de nossos doutrinadores, é o fato de que a soberania brasileira, como soberania de um Estado periférico, é uma soberania bloqueada, ou seja, enfrenta severas restrições externas e internas que a impedem de se manifestar em toda sua plenitude" (BERCOVICl, Gilberto. 0 poder constituinte do povo brasileiro: um roteiro de pesquisa sobre a crise constituinte. Lua Nova, São Paulo, CEDEC, n. 88, 2013, p. 316. Disponível em: http://dx.doi.org/10.1590/S010264452013000100010. Acesso em 30 nov. 2018).
} 
DIREITOS POLÍTICOS DE ESTRANGEIROS RESIDENTES NO BRASIL: CRITICA DOS PROJETOS LEGISLATIVOS NO CONTEXTO MIGRATÓRIO DA AMÉRICA LATINA

LUIZ ISMAEL PEREIRA CAMILO ONODA CALDAS

construção da independência, seja como pressão externa, para a abertura de setores estratégicos, como o de energia e petróleo. Vale lembrar, como disse Holloway, que há uma tensa relação entre capital e Estados nacionais, "a nationally fixed state to a globally mobile capital": ${ }^{11}$ o primeiro é marcado por uma fluidez expande suas barreiras para cada vez mais longe, enquanto o segundo se mantém imóvel por muito mais tempo, possui fronteiras que precisam ser debatidas no cenário internacional nos organismos supra estatais.

Para exemplificar a questão: o Brasil, em 2004, protocolou requerimento na Comissão de Limites da Plataforma Continental, criada pela Convenção das Nações Unidas sobre o Direito do Mar, solicitando a expansão da Plataforma Continental do país com o fim de aumentar "as oportunidades de descobertas de novas reservas de petróleo e gás, além do aproveitamento eventual de outros recursos vivos e não vivos na plataforma continental estendida"12, isto é, aumentar seu ganho econômico. Os Estados Unidos apresentaram protesto formal à ONU para impedir o pleito.

A população, por sua vez, é afetada direta e diariamente pelas decisões de soberania, bem como pela tensão territorial de influência entre capital internacional e Estado nacional, também se transfere de um conceito puramente político (porque jurídico nunca foi), passa a ser encarada como questão econômica. O Estado nacional precisa lidar com os nacionais, naturais ou naturalizados, e, além disso, com os estrangeiros que se deslocam para dentro de seus limites territoriais. Esse deslocamento pode ser causado por diversas questões: turismo, circulação de pessoas para estudos ou trabalho, abrigo de asilados políticos, deslocamentos por desastres

\begin{abstract}
${ }^{11}$ Nesse aspecto, é de destaque o seguinte trecho: "The contrast between the spatial liberation of the process of exploitation (mediated through the flow of capital as money), on the one hand, and the spatial definition of coercion (expressed in the existence of national states), on the other, is expressed as a contrast between the mobility of capital and the immobility of the state. The territorial definition of the state means that each state is immobile in a way that contrasts strongly with the mobility of capital. The national state can change its boundaries only with difficulty, whereas capital can move from one side of the world to the other within seconds. Where national states are solid, capital is essentially liquid, flowing to wherever in the world the biggest profits are to be made. Clearly there are obstacles to this flow, limits to this mobility. Crucially, the reproduction of capital depends on its (transitory) immobilisation in the form of productive capital, involving its embodiment in machinery, labour power, land, buildings, commodities. Other obstacles also impede the free flow of capital, such as state regulations or the existence of monopoly situations, but, in its most general and abstract form, money, capital is global, liquid and fast-flowing. Money knows no personal or national sentiments" (HOLLOWAY, John. Global capital and the National State. Capital \& Class, NY, New York University, 1994, 18:23, p. 33. Disponível em: http://dx.doi.org/10.1177/030981689405200103. Acesso em 30 nov. 2018).

12 SILVA, Alexandre Pereira da. 0 novo pleito brasileiro no mar: a plataforma continental estendida e o projeto Amazônia Azul. Revista Brasileira de Política Internacional, v. 56, n. 1, 2013, p. 117. Disponível em: http://dx.doi.org/10.1590/S0034-73292013000100006. Acesso em 30 nov. 2018. Para os documentos do Caso CLCS $02.2004 \quad$ LOS:
\end{abstract} http://www.un.org/depts/los/clcs_new/submissions_files/submission_bra.htm. 
ISSN 1981-3694

(DOI): $10.5902 / 1981369430115$

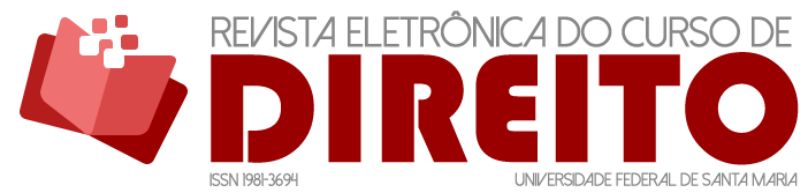

DIREITOS POLÍTICOS DE ESTRANGEIROS RESIDENTES NO BRASIL: CRITICA DOS PROJETOS LEGISLATIVOS NO CONTEXTO MIGRATÓRIO DA AMÉRICA LATINA

LUIZ ISMAEL PEREIRA CAMILO ONODA CALDAS

ambientais e, até mesmo, econômicos. Portanto, por ligação à própria efetividade de prestação de direitos sociais, o Estado-nação precisa se preocupar com o imigrante, também, como categoria econômica. Essas são as questões que mais se destacam na política internacional europeia dos últimos anos: do "Não" franco-holandês à Constituição da Europa, em 2005; ao Brexit britânico, em $2016^{13}$.

Tais elementos constitutivos que compõem o Estado-nação migram, portanto, de aspectos puramente jurídicos para econômicos, em especial no século XX. Portanto, a legislação dos Estados não pode deixar de lado a possibilidade de interferência do estrangeiro nos destinos políticos do país, como veremos adiante. Por fim, na passagem do fordismo para o pós-fordismo, destacamos maior fluidez em todos os seus aspectos de regulação das relações sociais.

O modo de produção capitalista comporta dois tipos de regimes de acumulação distintos. Em cada qual, o fluxo de imigrantes tem um significado distinto. No fordismo, regime desenvolvido a partir do século XX, os movimentos de imigração foram decorrências de políticas de Estado voltadas, no caso do Brasil, para atrair mão-de-obra para o campo e para indústria em período marcado pela abolição da escravatura e pelo crescimento da economia nacional. 0 tradicional modelo fordista, a partir do último quarto do século $X X$, começa a ser sucedido pelo pós-fordismo, cuja característica principal seria sua maior "flexibilidade". Um regime de acumulação mais "flexível” indica a existência de um modo de regulação distinto, ou seja, intervenção estatal diferente e arcabouço jurídico distinto.

Neste sentido, nota-se consequências em dois níveis: o primeiro, diz respeito à desregulamentação econômica e de mercados de capitais, diminuição dos direitos sociais, especialmente no campo do trabalho (perda das tradicionais garantias protetivas), da assistência social e da previdência; o segundo, relaciona-se às novas regulamentação - normatização privada - de organização do trabalho, voltadas para aumentar a produtividade, inclusive por intermédio de novas tecnologias e às custas da intensificação do labor, maximizando assim a lucratividade por intermédio da apropriação de valores produzido pelo trabalho. No regime de acumulação pós-fordista o trabalhador encontra-se em situação marcada pela ausência de estabilidade, precarização do trabalho e diminuição da proteção tradicional do direito do trabalho, situação decorrente dos novos modelos de contratação mais "flexíveis", ou seja, desregulamentados.

Os imigrantes no pós-fordismo inserem-se neste cenário de fluxo de mão-de-obra em nível global, marcado pelo enfraquecimento das políticas públicas e pela maximização do poder

13 Lembremos os enredos dos filmes Bem-vindo, de Philippe Lioret (2009); e Eu, Daniel Blake, de Ken Loach (2016). 
de exploração da força de trabalho. Neste cenário, tanto os elementos culturais como jurídicos se combinam para colocar estrangeiros (em especial uma parte deles, como veremos) em posição de inferioridade no mercado de trabalho. De um lado, o preconceito e discriminação, de modo consciente ou inconsciente, justificam piores condições de trabalho ou negação de direitos tradicionalmente reconhecidos aos trabalhadores "comuns".

De outro lado, o elemento jurídico regulamenta a situação de "irregularidade" e a “criminalização" do estrangeiro que se mantém constantemente ameaçado de ser deportado ou expulso do território no qual se encontra. Nesse contexto, o estrangeiro se distancia da organização sindical tradicional e dos serviços públicos comumente existentes para os cidadãos do país ${ }^{14}$. No plano econômico, portanto, o trabalhador estrangeiro insere-se dentro do regime de acumulação pós-fordista em condições ainda mais “flexíveis", leia-se, mais precária, mais instável e com menor potencialidade de proteção do aparelho jurídico-estatal.

Um aspecto relevante da situação do imigrante nesse momento de mudanças foi a crescente legislação sobre mendicância e vadiagem. Na abertura das fronteiras e aumento de população desempregada, o Estado-nação exerce a violência inerente ao poder político e passa a regular tais contravenções penais. "An important activity of the emerging national states was the territorial definition of coercion, the limiting of the mobility of the newly 'free' workers through measures such as the series of laws to define and control vagabondage"15. Uma legislação que tipifica as condutas comuns ao estrangeiro que efetua um deslocamento territorial em condições já precárias, sem uma assistência efetiva de direitos. Afinal, há uma profunda ausência de direitos econômicos, sociais e culturais para o estrangeiro, causando impacto sobre a efetivação de seus direitos fundamentais.

Assim, os aspectos da regulação da vida social do estrangeiro, ainda com maior fluidez na passagem do fordismo para o pós-fordismo, somar-se-á a outros meios de controle social das

\footnotetext{
14 “A criminalização, no caso de imigrantes em situação migratória irregular, pode induzi-los a uma 'vulnerabilidade estrutural'. Este conceito ajuda a explicar a dificuldade para migrantes em situação migratória irregular em acessar serviços. Trabalho e moradia ficam fora de seu alcance de gestão, mostrando que a dependência e a subordinação de tais sujeitos podem ser fomentadas por políticas públicas, leis e práticas sociais. Políticas públicas podem ser responsáveis pela falta de equidade no acesso aos serviços e direitos básicos de migrantes e refugiados, especialmente para os que se encontram em situação migratória irregular". LUSSI, Carmem. Políticas públicas e desigualdades na migração e refúgio. Psicol. USP, São Paulo, v. 26, n. 2, p. 136-144, Ago. 2015. Disponível em: http:// www.scielo.br/scielo.php?script=sci_arttext\&pid=S0103-65642015000200136\&lng=en\&nrm=iso. Acesso em 10 abr. 2017. http://dx.doi.org/10.1590/0103-6564D20140014.

15 HOLLOWAY, John. Global capital and the National State. Capital \& Class, NY, New York University, 1994, 18:23, p. 31. Disponível em: http://dx.doi.org/10.1177/030981689405200103. Acesso em 30 nov. 2018.
} 
liberdades, ao mesmo tempo em que o discurso econômico liberal propõe o enxugamento das políticas internas de efetivação de direitos sociais pela Administração Pública.

Conforme veremos a seguir, a inexistência de direitos políticos em relação ao estrangeiro conduz à dificuldade de buscar no Estado e no direito meios para eliminar ou diminuir a condição assimétrica e vulnerável na qual se encontra.

\section{DIREITO AO VOTO DE ESTRANGEIROS: PANORAMA NA AMÉRICA LATINA E DO BRASIL}

O direito de voto dos estrangeiros existe em diversos países do mundo e consiste em um aspecto fundamental para aperfeiçoar, ao menos do ponto de vista formal, o denominado “Estado Democrático de Direito".

O compromisso jurídico internacional do Brasil com o desenvolvimento de um Estado Democrático de Direito encontra-se consubstanciado na assinatura e ratificação do Pacto Internacional dos Direitos Civis e Políticos ${ }^{16}$, o qual trata a respeito do sufrágio em seu artigo 25, estabelecendo que:

Todos os cidadãos gozarão [...] sem restrições indevidas, dos seguintes direitos e oportunidades:

a) Participar na direção dos assuntos públicos, quer diretamente, quer por intermédio de representantes livremente eleitos;

b) Votar e ser eleito em eleições periódicas, autênticas, realizadas por sufrágio universal, por voto secreto que garanta a livre expressão da vontade dos eleitores;

c) Ter acesso, em condições gerais de igualdade, às funções públicas do seu país.

O Pacto, conforme se nota, menciona três aspectos fundamentais relacionados ao sufrágio: (i) a universalidade do direito; (ii) o direito de votar e de ser votado; (iii) o exercício periódico e secreto. No entanto, o documento em questão diz textualmente que tal direito é assegurado ao “cidadão", portanto, a princípio, exclui o estrangeiro, ou seja, o não-cidadão para uma leitura mais tradicional que atrela a cidadania à nacionalidade.

A problemática do direito político do estrangeiro surge especialmente no momento em que este considerado não-cidadão estabelece residência fora de seu território pátrio, manifestando assim uma intencionalidade de permanência, ou seja, o intuito de integrar-se

\footnotetext{
16 Pacto Internacional sobre Direitos Civis e Políticos foi adotado pela XXI Sessão da Assembleia Geral das Nações Unidas, em 16 de dezembro de 1966. Em vigência no Brasil desde 07 de julho de 1992. Disponível em: http://www.planalto.gov.br/ccivil_03/decreto/1990-1994/D0592.htm. Acesso em 01 nov. 2017.
} 
ISSN 1981-3694

(DOI): $10.5902 / 1981369430115$

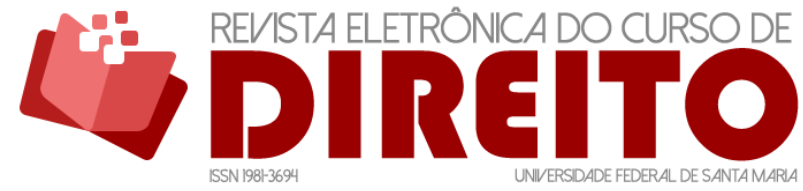

DIREITOS POLÍTICOS DE ESTRANGEIROS RESIDENTES NO BRASIL: CRITICA DOS PROJETOS LEGISLATIVOS NO CONTEXTO MIGRATÓRIO DA AMÉRICA LATINA

LUIZ ISMAEL PEREIRA CAMILO ONODA CALDAS

socialmente (e economicamente) em determinada localidade em relação a qual não detém originalmente vínculos jurídicos típico de um cidadão nacional. Nessa situação, estabelece-se um contraste entre a situação materialmente constituída e a formalmente (juridicamente) estabelecida.

O estrangeiro nessas condições, salvo na excepcional hipótese de ser agente diplomático, submete-se à legislação nacional e à autoridade do Estado no qual se encontra. Contudo, quando desprovido de direitos políticos, não dispõe de meios juridicamente estabelecidos para escolher, direta ou indiretamente, os Poderes Executivo e Legislativo, portanto, encontra-se desprovido de mecanismos institucionais para constituir o corpo de representantes políticos em tais poderes (seja votando ou sendo votado) e assim influenciar a atividade exercida pelo legislador e pelo administrador público.

Se por um lado a preocupação com a segurança e estabilidade nacional historicamente tem servido como argumento para afastar a participação política de estrangeiros; de outro, sua presença maciça acaba por suscitar a possibilidade de estender-lhes os direitos políticos tradicionalmente declarados aos cidadãos nacionais, sobretudo devido a relevância do ponto de vista social e econômico. Neste sentido, é comum surgirem três condições para o exercício do direito ao voto do estrangeiro: (i) Residência no território por período mínimo ou sob determinada forma; (ii) Registro (alistamento) perante órgãos competentes; (ii) Existência de reciprocidade entre Estados (neste caso, o cidadão de um país " $A$ " tem direito a votar em um país “ $B$ ” caso este país " $A$ " reconheça direitos políticos equivalentes aos cidadãos oriundos do país “B”).

O Brasil, conforme veremos a seguir, não concede aos estrangeiros nenhum direito político ligado ao sufrágio, seja o de votar ou o de ser votado. Encontra-se, assim, em situação distinta de outros países que the são próximos historicamente ou socialmente: Portugal reconhece aos estrangeiros o direito de votar e ser votado em eleições locais, estabelecendo como condição a residência mínima no território de três anos e a existência de reciprocidade (Art. 15, inciso 4 da Constituição da República Portuguesa); ademais, aos estrangeiros oriundos de Estados de língua portuguesa, caso do Brasil, dispensa tempo mínimo de residência permanente no país e amplia o direito para eleições nacionais (com ressalvas, conforme Art. 15, inciso 3 do mesmo diploma legal); o Chile reconhece direito de votar em eleições locais e nacionais após cinco anos de residência no país (Art. 14 da Constituição Política da República do Chile); e o Uruguai, desde a Constituição de 1952, reconhece em seu artigo 78 direito de voto em eleições nacionais a quem reside há mais de quinze anos no país e que tenha "boa conduta, 
com família na República" e seja possuidor de "algum capital em giro ou propriedade no país" ou esteja "professando alguma ciência, arte ou indústria"17.

A Venezuela, por fim, reconhece direito de voto ao estrangeiro, restringindo-o às eleições locais e estaduais e condicionando à residência mínima de dez anos no país (Art. 64 da Constituição da República Bolivariana da Venezuela). Importante destacar ainda que Uruguai, Chile, Venezuela e Brasil integram o bloco econômico do Mercosul, ou seja, a integração econômica existente, ainda que bastante limitada, não se reflete em termos de reciprocidade de direitos políticos entre os cidadãos destes países. No mundo, diversos outros países reconhecem o direito de voto a estrangeiros ${ }^{18}$.

Como é sabido, o Brasil vivenciou um período de redemocratização após 1985 com fim da ditadura militar que se iniciara com o golpe de Estado de março de 1964, responsável por depor do presidente eleito João Goulart. A Constituição Federal de 1988 foi o principal documento jurídico resultante deste processo político.

Atualmente, a Constituição brasileira veda aos estrangeiros a possibilidade de votarem e serem votados em eleições de todas as esferas. ${ }^{19}$ Após sua promulgação, um movimento de mudanças legislativas começou a ocorrer. A recente aprovação da “Lei de Migração" (Lei federal $\mathrm{n}^{\circ} 13.445$, de 24 de maio de $2017^{20}$ ) revogou a Lei federal $\mathrm{n}^{\circ} 6.815$, de 19 de agosto de 1980 , que tratava anteriormente a matéria e pôs fim a determinação de que o "estrangeiro admitido no território nacional não pode exercer atividade de natureza política, nem se imiscuir, direta ou indiretamente, nos negócios públicos do Brasil"21, criminalizando tal conduta e punindo-a com detenção e expulsão do estrangeiro ${ }^{22}$. Tratava-se de notória restrição ao exercício de direito de manifestação e liberdade de expressão (prerrogativa diretamente relacionada aos direitos políticos), invocada inclusive recentemente pela Polícia Federal contra estrangeiros engajados

17 URUGUAl. Constitución de la republica, de 16 de diciembre de 1951. Disponível em: http://www.pgdlisboa.pt/leis/lei_mostra_articulado.php?nid=2160\&tabela=leis. Acesso em: 01 abr 2017.

18 HAUDUK, Ron; WUCKER, Michele. Immigrant Voting Rights Receive More Attention. Migration Policy Institute. Disponível em: http://www.migrationpolicy.org/article/immigrant-voting-rights-receive-moreattention. Acesso em: 10 abr. 2017.

${ }^{19}$ A restrição ao voto de estrangeiros é mencionada textualmente no art. 14 , §§ $2^{\circ}$ e $3^{\circ}$, da Constituição Federal de 1988, Capítulo IV (“Dos direitos políticos”) do Título II (“Dos Direitos e Garantias Fundamentais").

20 BRASIL. Código Civil, Lei federal $\mathrm{n}^{\circ} 10.406$, de 10 de janeiro de 2002. Disponível em: http://www.planalto.gov.br/ccivil_03/_ato2015-2018/2017/lei/L13445.htm Acesso em: 10 abr. 2017.

21 Art. 107 do Estatuto do Estrangeiro. (BRASIL. Estatuto do estrangeiro, Lei federal $\mathrm{n}^{\circ} 6.815$, de 19 de agosto de 1980. Disponível em: http://www.planalto.gov.br/ccivil_03/leis/L6815.htm. Acesso em: $10 \mathrm{abr}$. 2017).

${ }^{22}$ Artigo 125 do mesmo diploma legal. 
DIREITOS POLITICOS DE ESTRANGEIROS RESIDENTES NO BRASIL: CRITICA DOS PROJETOS LEGISLATIVOS NO CONTEXTO MIGRATÓRIO DA AMÉRICA LATINA

LUIZ ISMAEL PEREIRA CAMILO ONODA CALDAS

nos protestos populares contra o golpe parlamentar de Estado ${ }^{23}$ - ou, o Impeachment de 2016 perpetrado contra a então Presidenta Dilma Rousseff ${ }^{24}$.

Por fim, nota-se que o Brasil, dentro de um cenário de mudança legislativa e de crescimento de fluxos migratórios oriundos especialmente da América Latina, estuda a possibilidade de alterar sua legislação e, finalmente, reconhecer direitos políticos àqueles que não são cidadãos brasileiros.

Destaca-se o fato de que o Constituinte de 1987 optou por desatrelar a cidadania da nacionalidade, ou seja, cidadania é uma condição que só pode ser exercida em pleno gozo de direitos civis, políticos e sociais. ${ }^{25}$ Ao mesmo tempo em que a desatrela da cidadania, abrindo a condição ao estrangeiro, restringi sua ação política. Essa visão histórica, herdada da construção clássica de Marshal, pela qual a cidadania se confunde com o desenvolvimento histórico da conquista de tais direitos, vai de encontro à tradição liberal que construiu a confusão entre nacionalidade e cidadania desde a Declaração dos Direitos do Homem e do Cidadão, de 1789, refletida nos textos constitucionais franceses e daí para o mundo. ${ }^{26}$

A resposta, para alguns, será o reconhecimento de uma ética intercultural, como proposta por Boaventura de Souza Santos, ${ }^{27}$ mas que não denota o verdadeiro sentido da exclusão do estrangeiro da ordem da cidadania, em especial quando temos como base a realidade latino americana constituída por Estados plurinacionais, ainda que não

\footnotetext{
${ }^{23}$ JINKINGS, Ivana; DORIA, Kim; CLETO Murilo; SINGER, André. Por que gritamos golpe?: para entender o impeachment e a crise política no Brasil. São Paulo: Boitempo, 2016.

24 “A Federação Nacional dos Policiais Federais - FENAPEF vem à público informar sobre a proibição legal da participação de estrangeiros em manifestações políticas no Brasil, diante das notícias veiculadas na imprensa sobre a entrada de estrangeiros vindos da Venezuela, Peru, da Argentina e do Paraguai, com o fim de protestar contra o Impeachment da Presidente Dilma Rousseff, no próximo domingo, 17. 0 Estatuto do Estrangeiro (Lei $n^{\circ} 6815 / 80$, art.107) dispõe que o estrangeiro admitido no território nacional não pode exercer atividade de natureza política, nem participar de desfiles, passeatas, comícios e reuniões de qualquer natureza no Brasil, submetendo o infrator à pena de detenção de 1 (um) a 3 (três) anos e expulsão do País". FEDERAÇÃO NACIONAL DOS POLICIAIS FEDERAIS. Nota à Imprensa: estrangeiros que participarem de atos políticos podem ser detidos e expulsos do país. Disponível em: http://www.fenapef.org.br/nota-a-imprensa-estrangeiros-que-participarem-de-atos-politicos-podem-serdetidos-e-expulsos-do-pais/. Acesso em: 10 abr. 2017.

25 Esse é o entendimento de Gianpaolo Poggio Smanio quando reconstrói as dimensões da cidadania, do Estado liberal, ao cosmopolitismo (SMANIO, Gianpaolo Poggio. As dimensões da cidadania. Revista da ESMP. Ano 2, jan./jun. 2009, pp. 13-23).

${ }^{26}$ Sobre a história da cidadania no constitucionalismo francês, em especial a tensão entre a positivação nacionalista e a visão histórica: REIS, Rossana Rocha. Políticas de nacionalidade e políticas de imigração na França. Revista Brasileira de Ciências Sociais, São Paulo, v. 14, n. 39, p. 118-138, fev. 1999. Disponível em: http://dx.doi.org/10.1590/S0102-69091999000100007. Acesso em 01 dez. 2018.

27 Destaca-se, do autor: SANTOS, Boaventura de Souza. Uma concepção multicultural dos direitos humanos. Lua Nova. № 39, 1997, pp. 105-124. Disponível em: http://dx.doi.org/10.1590/S010264451997000100007. Acesso em 01 dez. 2018.
} 
declaradamente reconhecidos. Se, nessa visão intercultural, o "conceito de cidadania deve levar em conta as diferenças, na medida em que os direitos de cidadania, originalmente definidos por e para os homens brancos, não podem dar resposta as necessidades específicas dos grupos minoritários", ${ }^{28}$ ela se centra em questões culturais como se essa não fossem, propriamente, políticas e econômicas, daí o erro do cosmopolitismo.

Como aponta Herrera Flores, esse multiculturalismo tenta escapar das questões mais profundas que aparecem com os resultados da globalização, ou "os números do fim da história”. Antes disso, aponta que é necessário reconhecer que "os problemas culturais estão estreitamente interconectados com os problemas políticos e econômicos". Afinal, a cultura "é uma resposta, uma reação à forma como vão se constituindo e se desdobrando as relações sociais, econômicas e políticas em um tempo e um espaço determinados". ${ }^{29}$

A seguir passaremos a analisar as propostas existentes neste sentido.

\section{VOTO DE ESTRANGEIROS RESIDENTES NO BRASIL: PROPOSTAS DE EMENDA CONSTITUCIONAL VISANDO AMPLIAÇÃO DE DIREITOS POLÍTICOS}

No nível constitucional, desde a redemocratização iniciada em 1985, surgiram no Brasil diversos projetos voltados para estender os direitos políticos dos cidadãos não-brasileiros. A seguir, faremos uma descrição sintética de todas as propostas formuladas e, mais adiante, desenvolveremos uma análise mais detalhada do conteúdo, justificativa e viabilidade daquelas que estão em tramitação no momento.

De início, sinteticamente, identificamos que os órgãos do Poder Legislativo Federal, partindo das competências constitucionais estabelecidas e se utilizando do Poder Constituinte Derivado, apresentou diversas Propostas de Emenda Constitucional (PEC) voltadas a tratar do tema do exercício do direito ao voto por cidadãos não-brasileiros residentes no país. Alguns projetos foram arquivados e outros seguem com a possibilidade serem votadas.

${ }^{28}$ WOLKMER, Maria de Fátima S. Cidadania cosmopolita, ética intercultural e globalização neoliberal. Revista Sequência. $N^{\circ}$ 46, jul. 2013, p. 37. Disponível em: https://periodicos.ufsc.br/index.php/sequencia/article/view/15290. Acesso em: 30 ago. 2018.

29 HERRERA FLORES, Joaquín. A (re)invenção dos direitos humanos. Florianópolis: Fundação Boiteux, 2009 , pp. 152-154. 0 argumento fica evidente no caso latino americano quando se nota a mudança das estruturas culturais com a conquista eleitoral na Bolívia, onde o povo cuja cultura predominantemente é quéchua e aimará, passa a ter acesso ao ensino superior que antes era unicamente em castelhano, sentido os impactos da falta do ensino formal em sua própria língua (LINERA, Álvaro Garcia. A Potência Plebeia: ação coletiva e identidades indígenas, operárias e populares na Bolívia. São Paulo: Boitempo, 2010, p. 303). 
DIREITOS POLÍTICOS DE ESTRANGEIROS RESIDENTES NO BRASIL: CRITICA DOS PROJETOS LEGISLATIVOS NO CONTEXTO MIGRATÓRIO DA AMÉRICA LATINA

A tabela a seguir apresenta uma visão geral da cronologia dos projetos e de sua situação no momento:

Tabela 1- Cronologia e situação de PECs - Câmara de Deputados - Brasil

\begin{tabular}{|c|c|l|l|l|}
\hline PEC N & DATA & \multicolumn{1}{|c|}{ AUTOR } & PARTIDO & \multicolumn{1}{|c|}{ SITUAÇÃO } \\
\hline $347 / 2013$ & $05 / 11 / 2013$ & Carlos Zarattini & PT/SP & Tramita apensado a outro. \\
\hline $119 / 2011$ & $06 / 12 / 2011$ & Roberto Freire & PPS/SP & Em tramitação com apenso. \\
\hline $401 / 2005$ & $31 / 05 / 2005$ & $\begin{array}{l}\text { Orlando } \\
\text { Fantazzini }\end{array}$ & PT/SP & Arquivada em 2008 \\
\hline $371 / 2001$ & $12 / 06 / 2001$ & Marcos Cintra & PFL/SP & Arquivada em 2003 \\
\hline $560 / 1997$ & $24 / 11 / 1997$ & Fetter Junior & PPB/RS & Arquivada em 2003 \\
\hline $104 / 1995$ & $24 / 05 / 1995$ & Alvaro Valle & PL/RJ & Arquivada em 2003 \\
\hline $72 / 1991$ & $21 / 02 / 1991$ & José Serra & PSDB/SP & $\begin{array}{l}\text { Julgada prejudicada desde 1994 pelo parecer } \\
03 / 94\end{array}$ \\
\hline $29 / 1991$ & $12 / 08 / 1991$ & Victor Faccioni & PDS/RS & $\begin{array}{l}\text { Julgada prejudicada desde 1994 pelo parecer } \\
03 / 94\end{array}$ \\
\hline
\end{tabular}

Fonte: elaborado pelos autores.

Tabela 2 - Cronologia e situação de PECs - Senado Federal - Brasil

\begin{tabular}{|l|c|l|l|}
\hline PEC N $^{\circ}$ & DATA & \multicolumn{1}{c|}{ AUTOR } & \multicolumn{1}{c|}{ SITUAÇÃO } \\
\hline $25 / 2012$ & $15 / 05 / 2012$ & Diversos Senadores & \\
\hline $14 / 2007$ & $06 / 03 / 2007$ & Alvaro Dias & Em tramitação \\
\hline $88 / 2007$ & $04 / 10 / 2007$ & Sergio Zambiasi & Arquivada em 2014 \\
\hline $7 / 2002$ & $01 / 03 / 2002$ & Alvaro Dias & Arquivada em 2007 \\
\hline $33 / 2002$ & $28 / 11 / 2002$ & Mozarildo Cavalcanti & Arquivada em 2007 \\
\hline $61 / 1999$ & $25 / 06 / 1999$ & Alvaro Dias & Arquivada em 2001 \\
\hline
\end{tabular}

Fonte: elaborado pelos autores.

Observa-se, portanto, que há dois projetos tramitando atualmente: a PEC 119/2011 e a PEC 347/2013 (apensada àquela e, portanto, tramitando em conjunto). Partindo da dicotomia política "direita" e "esquerda", a tabela acima mostra, ainda, que partidos políticos de

\footnotetext{
${ }^{30}$ Aloysio Nunes Ferreira, Senador Aécio Neves, Senadora Ana Amélia, Senador Anibal Diniz, Senador Antonio Carlos Valadares, Senador Armando Monteiro, Senador Blairo Maggi, Senador Casildo Maldaner, Senador Cássio Cunha Lima, Senador Ciro Nogueira, Senador Cristovam Buar, Senador Cyro Miranda, Senador Eduardo Braga, Senador Eduardo Suplicy, Senador Flexa Ribeiro, Senador Francisco Dornelles, Senador Inácio Arruda, Senador Jarbas Vasconcelos, Senador Jayme Campos, Senador Mário Couto, Senador Paulo Paim, Senador Pedro Simon, Senador Randolfe Rodrigues, Senador Ricardo Ferraço, Senador Roberto Requião, Senador Romero Jucá, Senador Sergio Souza, Senador Vicentinho Alves, Senador Wellington Dias.
} 

CRITICA DOS PROJETOS LEGISLATIVOS NO CONTEXTO MIGRATÓRIO DA AMÉRICA LATINA

diferentes orientações políticas apresentaram projetos neste sentido, ainda que, no Brasil, parte do espectro de extrema direita tenha assumido nos últimos anos um discurso abertamente hostil aos imigrantes da América Latina e da África, o que ficou fartamente evidenciado quando da aprovação da nova "Lei da Migração" ${ }^{31}$. Na tabela acima excluímos a PEC 57/1995 de autoria de Emerson Olavo Pires - PSDB/RO, uma vez que propunha o voto facultativo, mantendo a restrição aos estrangeiros, portanto, ainda que faça alusão ao tema, não modificaria o direito ao voto.

A motivação para que partidos com orientações políticas divergentes manifestem uma vontade comum se explica tanto pelo interesse de candidatos em determinados nichos eleitorais, como também reflete um ponto de convergência entre forças políticas antagônicas: as correntes de "esquerda" - historicamente preocupadas em ampliar a cidadania ativa para trabalhadores e camadas populares - e as correntes de direita - cujo viés liberal enseja a defesa das liberdades políticas dos indivíduos (ainda que a tradição liberal, historicamente, não esteja necessariamente associada à ampliação da cidadania ativa para camadas populares ${ }^{32}$ ). Neste sentido, a PEC 347/2013 - proposta pelo Partido dos Trabalhadores (PT) - destaca que os imigrantes "vem com seu trabalho participando da construção de nosso País e devem ter esse direito [ao voto]"33. De outra parte, a PEC 61/1999 - proposta pelo Senador Alvaro Dias, atualmente no PV (Partido Verde), mas oriundo do PSDB (Partido da Social Democracia Brasileira) de orientação neoliberal - argumenta que o direito de voto ao estrangeiro "se fundamenta nas tradições liberais de nosso povo"34.

Quanto ao conteúdo de cada uma das propostas, podemos apresentar uma síntese por meio da seguinte tabela, que resume qual a abrangência das propostas de ampliação de direitos políticos, bem como quais os deveres exigidos para estar apto ao exercício destas prerrogativas:

\footnotetext{
${ }^{31}$ OLIVEIRA, André de. Xenofobia, bomba e detenções: 24 horas tensas após ato contra lei de migração. Disponível em: http://brasil.elpais.com/brasil/2017/05/04/politica/1493859671_902222.html. Acesso em: 09 abr. 2017; FILGUEIRAS, Isabel. Movimento da extrema direita pede que Temer vete nova lei. Disponível em: http://www.opovo.com.br/jornal/politica/2017/04/movimento-da-extrema-direita-pede-que-temervete-nova-lei.html. Acesso em: 09 abr. 2017.

32 BOBBIO, Norberto. Existe uma ciência política marxista? In: ARAÚJO, Braz José; FIGUEIREDO, Eurico de Lima (org.). 0 marxismo e o Estado. Trad. Federica L. Boccardo e Rennée Levie. Rio de Janeiro: Graal, 1979, p. 43.

33 BRASIL. Câmara dos Deputados. Proposta de Emenda Constitucional $n^{\circ}$ 347/2013. Permite que os estrangeiros residentes em território brasileiro por mais de quatro anos e legalmente regularizados alistem-se como eleitores. Disponível em: http://www.camara.gov.br/proposicoesWeb/fichadetramitacao?idProposicao=599448. Acesso em 10 abr. 2017.

${ }^{34}$ BRASIL. Câmara dos Deputados. Proposta de Emenda Constitucional n 61/1999. Dá nova redação aos $\S \S 2^{\circ}$ e $3^{\circ}$ do artigo 14 da Constituição Federal (concede cidadania ativa e passiva ao estrangeiro, restrita a nível municipal). Disponível em: https://www25.senado.leg.br/web/atividade/materias/-/materia/40987. Acesso em 10 abr. 2017.
} 
Tabela 3 - Conteúdo de PECs sobre voto de estrangeiro - Câmara dos Deputados - Brasil

\begin{tabular}{|l|l|l|l|}
\hline \multicolumn{1}{|c|}{ PEC N } & \multicolumn{1}{|c|}{ DIREITO A } & ESFERA & \multicolumn{1}{c|}{ CONDIÇÃO } \\
\hline $347 / 2013$ & Votar & Todas & Residência mínima de 4 anos no país \\
\hline $119 / 2011$ & $\begin{array}{l}\text { Votar e ser } \\
\text { votado }\end{array}$ & Municipal & $\begin{array}{l}\text { Residência mínima no país de } \\
\text { (i) Mais de 05 anos para votar. } \\
\text { (ii) Mais de 10 anos ser votado. }\end{array}$ \\
\hline $401 / 2005$ & Votar & Todas & Residência mínima de 5 anos no país \\
\hline $371 / 2001$ & Votar & Municipal & Residência no país \\
\hline $560 / 1997$ & Votar & Todas & $\begin{array}{l}\text { Residência há pelo menos } 5 \text { anos e expressar-se em idioma } \\
\text { nacional }\end{array}$ \\
\hline $104 / 1995$ & Votar & Municipal & Residência há mais de 5 anos \\
\hline $72 / 1991$ & Votar & Todas & Residência há mais de 5 anos no país \\
\hline $29 / 1991$ & Votar & Municipal & Residência há mais de 5 anos no município \\
\hline
\end{tabular}

Fonte: elaborado pelos autores.

Tabela 4 - Conteúdo de PECs sobre voto de estrangeiro - Senado Federal - Brasil

\begin{tabular}{|l|l|l|l|}
\hline \multicolumn{1}{|c|}{ PEC N } & \multicolumn{1}{|c|}{ DIREITO } & \multicolumn{1}{c|}{ ESFERA } & \multicolumn{1}{c|}{ CONDIÇÃO } \\
\hline $25 / 2012$ & Votar e ser votado & Municipal & Residência permanente no país \\
\hline $14 / 2007$ & Votar e ser votado ${ }^{35}$ & Municipal & Residência permanente no país \\
\hline $88 / 2007$ & Votar & Todas & $\begin{array}{l}\text { Residência mínima de 5 anos no país e ser } \\
\text { maior de 16 anos }\end{array}$ \\
\hline $7 / 2002$ & $\begin{array}{l}\text { Votar e ser votado para o } \\
\text { cargo de vereador }\end{array}$ & Municipal & Residência no país \\
\hline $33 / 2002$ & Votar e ser votado & Todas & Domicílio no país ${ }^{36}$ \\
\hline $61 / 1999$ & $\begin{array}{l}\text { Votar e ser votado para o } \\
\text { cargo de Vereador }\end{array}$ & Municipal & Domicílio no país ${ }^{37}$ \\
\hline
\end{tabular}

Fonte: elaborado pelos autores.

Todos os projetos acima apontados apresentam, juntamente com o conteúdo proposto, uma justificativa correspondente. A seguir, passaremos a analisar estes dois elementos.

\footnotetext{
35 No caso, o direito de ser votado ficaria restrito apenas ao cargo de vereador, portanto, o projeto não possibilita que estrangeiro se torne chefe do Poder Executivo Municipal.

${ }^{36} 0$ projeto fala textualmente em "estrangeiro domiciliado", conceito jurídico mais abrangente, pois inclui não apenas local de residência, como também aquele no qual exerce suas atividades profissionais. Residência, por sua vez, é o local onde o sujeito mora com intuito permanente, portanto, um conceito menos abrangente.

${ }^{37}$ Idem ao projeto acima.
} 
ISSN 1981-3694

(DOI): $10.5902 / 1981369430115$

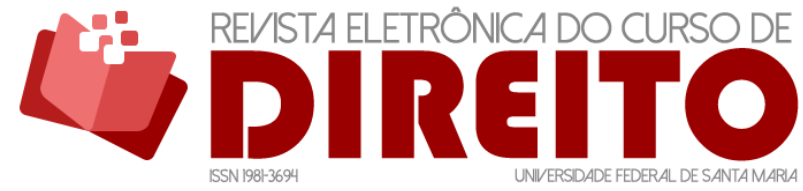

DIREITOS POLÍTICOS DE ESTRANGEIROS RESIDENTES NO BRASIL: CRITICA DOS PROJETOS LEGISLATIVOS NO CONTEXTO MIGRATÓRIO DA AMÉRICA LATINA

LUIZ ISMAEL PEREIRA CAMILO ONODA CALDAS

Quanto ao conteúdo das propostas, conforme apontamos anteriormente, a residência no país em que se pretende exercer o direito ao voto costuma ser uma das condições para seu exercício. No caso do Brasil, nota-se que este requisito aparece em todos as Propostas de Emenda Constitucional e, em alguns casos, a duração mínima de residência é exigida. A PEC 560/1997, por sua vez, era o único que adicionava como requisito o domínio do idioma nacional do Brasil.

Outro aspecto relevante comum às diversas propostas apresentadas é a restrição dos direitos políticos à esfera municipal, portanto, a exclusão de participação política em relação ao governo distrital, estadual e federal. Considerando o sistema federativo brasileiro, ao contrário de outros países, centralizam-se as competências legislativas e o poder administrativo na União Federal e não nos Estados-membros, o que salta aos olhos nas Propostas, pois não se vislumbra a razão pela qual os projetos apresentados tenham caráter tão restritivo, excluindo a esfera estadual.

O embate entre ampliar o direito de voto para todos os níveis (federal, estadual, municipal e distrital) ou restringir para a esfera municipal pode ser encontrado claramente no conflito entre as duas PECs que tramitam atualmente na Câmara dos Deputados: a PEC 347/2013 propõe direito de voto em todos os níveis e a PEC 119/2011 propõe tal direito apenas no nível municipal. A PEC de 2013 é proposta por um parlamentar do Partido dos Trabalhadores (PT) cuja orientação política está mais à esquerda que a do PPS, partido do deputado que propôs a PEC 119/2011, mais restritiva. Por outro lado, esta última possui um ponto mais avançado: a possibilidade do estrangeiro não apenas de votar, mas também de ser votado (ainda que apenas no nível municipal).

No Senado Federal, por sua vez, apenas subsistem propostas com caráter bastante restritivo. As duas atualmente em tramitação (PEC 25/2012 e PEC 14/2007) apenas garantem exercício de direitos políticos no nível municipal. A proposta de 2007 é ainda mais restritiva, pois reduz o direito de ser votado apenas para o cargo de vereador, portanto, exclui o estrangeiro da possibilidade ser candidatar a prefeito do município (o direito de votar, por sua vez, fica garantido aos cargos do Poder Legislativo e Executivo). Há, contudo, um aspecto positivo nos dois projetos do Senado Federal em tramitação: ambos são mais brandos no que tange ás condições para adquirir os direitos políticos: nas duas propostas, exige-se apenas residência no país, sem que haja um tempo mínimo na condição de residente.

A amplitude dos direitos políticos dos estrangeiros, especialmente no nível federal, é extremamente relevante justamente porque, no Brasil, compete especialmente ao Poder 
Legislativo Federal legislar sobre matérias que dizem respeito aos direitos dos imigrantes. Neste sentido, destacamos a recente "Lei de Migração", Lei n 13.445 de 24 de maio de 2017. Não obstante os avanços em relação ao marco anterior (Lei n 6.815 de 19 de agosto de 1980, criada durante o regime militar sob o princípio de Segurança Nacional), a nova lei já tem sido objeto de crítica por entidades de defesa dos direitos dos imigrantes, justamente por se entender que diversas normas, presente e ausentes, mantém a condição de vulnerabilidade dos estrangeiros residentes no país $^{38}$. Assim, se os imigrantes permanecerem excluídos do direito de votar e serem votados no nível federal, dificilmente exercerão pressão política para criação leis voltadas a protege-los, bem como para adoção de políticas públicas que possam favorece-los.

Quanto à justificativa das PEC's, encontramos alguns pontos em comum na retórica política dos parlamentares propostas. Basicamente, podemos sintetizar os discursos em três pontos: (i) a constituição histórica brasileira por meio da imigração; (ii) a necessidade de integrar o estrangeiro ao local no qual ele reside; (iii) a ampliação dos direitos políticos e da democracia. É importante mencionar que a PEC 347/2013, a mais recente, cita expressamente os movimentos migratórios latino-americanos e africanos dos últimos anos. De outra parte, o projeto acaba por reforçar o mito ${ }^{39}$ de importação qualificada de mão-de-obra europeia versus a ausência de qualificação por parte de imigrantes oriundos de outros países. 0 autor do projeto afirma:

Mais recentemente tem chegado ao nosso País além de milhares de imigrantes procedentes da América Latina e da África (bolivianos, haitianos, nigerianos e outros) também profissionais de alta qualificação, cientistas, pesquisadores, engenheiros e técnicos, cuja origem, como regra, é do continente europeu (portugueses, espanhóis, russos e outros). Também não podemos deixar de fazer uma referência especial à migração de asiáticos, particularmente de chineses e coreanos. ${ }^{40}$

38 ASSOCIAÇÃO BRASILEIRA DE ANTROPOLOGIA. Análise crítica sobre o PL 2516/14. Disponível: https://jornalggn.com.br/sites/default/files/documentos/analise_critica_do_pl2516_comite_migracoes_e deslocamentos_da_aba1_co_pia_1.pdf. Acesso em: 09 abr. 2017.

${ }^{39} \mathrm{E}$ eis porque chamamos de mito: "Além da atividade da costura, vale destacar um significativo grupo de profissionais liberais, entre eles, médicos e dentistas, os quais, além de enfrentarem o problema da regularização no país, são desafiados também pela dificuldade da revalidação dos seus títulos acadêmicos, cujo processo é lento e dispendioso. A área de serviços e do comércio ambulante é outro setor que absorve parte dessa mão-de-obra boliviana que chega a São Paulo, em geral indocumentada". SILVA, Sidney Antonio da. Bolivianos em São Paulo: entre o sonho e a realidade. Estudos Avançados, São Paulo, v. 20, n. 57, p. 157-170. Ago. 2006. DOI: http://dx.doi.org/10.1590/S0103-40142006000200012. Acesso em: 07 abr. 2017. Acesso em 07 abr. 2017.

40 BRASIL. Câmara dos Deputados. Proposta de Emenda Constitucional $n^{\circ} 347 / 2013$. Permite que os estrangeiros residentes em território brasileiro por mais de quatro anos e legalmente regularizados alistem-se como eleitores. Disponível em: 
DIREITOS POLITICOS DE ESTRANGEIROS RESIDENTES NO BRASIL: CRITICA DOS PROJETOS LEGISLATIVOS NO CONTEXTO MIGRATÓRIO DA AMÉRICA LATINA

LUIZ ISMAEL PEREIRA CAMILO ONODA CALDAS

A percepção da desqualificação da mão-de-obra não-europeia não é fruto de um acaso. Além do peso do preconceito (responsável por naturalizar certos grupos étnicos e nacionais a determinadas profissões), as dificuldades de regularização de visto para o exercício da profissão e para validar títulos acadêmicos acaba por criar uma invisibilidade acerca das habilidades profissionais de certos grupos de imigrantes.

Finalmente, em relação à viabilidade de aprovação das propostas no Brasil, desconsiderando as recorrentes crises políticas que tem paralisado a atividade legislativa no Brasil, há diversos elementos que dificultam a extensão de direitos políticos para os estrangeiros residentes no país.

O primeiro obstáculo consiste na presença de discurso de ódio e de preconceito por questões étnicas e de origem nacional. O Brasil, muitas vezes, é visto como país da "diversidade racial", uma sociedade de cordialidade e tolerância, o que produz o mito da democracia racial no país ${ }^{41}$. Contudo, tem sido crescente o registro do discurso de ódio no Brasil, com origem em preconceitos diversos (etnia, gênero, orientação sexual, identidade de gênero, origem nacional ou regional, raça etc.), inclusive entre sujeitos que exercem cargos parlamentares no Brasil ${ }^{42}$.

A legislação brasileira criminaliza racismos e algumas formas de preconceito ${ }^{43}$. Assim, em regra, tais práticas ficam submersas. Contudo, sempre emergem nas situações em que privilégios históricos são minimamente ameaçados por leis e políticas públicas voltadas à defesa das minorias. ${ }^{44}$

http://www.camara.gov.br/proposicoesWeb/fichadetramitacao?idProposicao=599448. Acesso em $10 \mathrm{abr}$. 2017.

41 ALMEIDA, Silvio Luiz de. Racismo. Enciclopédia Jurídica. Disponível em: https: //enciclopediajuridica.pucsp.br/verbete/92/edicao-1/racismo. Acesso em: 09 abr. 2017.

42 FEDERICO, Vitor. Bolsonaro vê imigrantes como "ameaça" e chama refugiados de "a escória do mundo". Disponível em: http://www.jornalopcao.com.br/ultimas-noticias/bolsonaro-ve-imigrantes-como-ameacae-chama-refugiados-de-a-escoria-do-mundo-46043/. Acesso em: 09 abr. 2017.

${ }_{43}$ BRASIL. Lei federal $n^{\circ}$ 7.716, 5 de janeiro de 1989. Define os crimes resultantes de preconceito de raça ou de cor. Disponível em: http://www.planalto.gov.br/ccivil_03/leis/L7716.htm. Acesso em: 10 abr. 2017.

44 "De um lado, a classe média é contra a politização, quer apenas manter seu modo de vida, ser deixada em paz para viver e trabalhar, e é por isso que tende a apoiar os golpes autoritários que prometem por fim na louca mobilização política da sociedade, de modo que todos possam voltar ao trabalho; de outro, os integrantes da classe média, disfarçados de maioria moral, trabalhadora, patriótica e ameaçada, são os maiores instigadores da mobilização comunitária de base, disfarçada de populismo de direita" (ZIZEK, Slavoj. Em defesa das causas perdidas. Tradução de Maria Beatriz de Medina. São Paulo: Boitempo, 2011, pp. 284-285). Tal atitude não é inédita na História da América Latina: ver HARTLYN, Jonathan; VALENZUELA, Arturo. A democracia na América Latina após 1930. In: BETHELL, Leslie (Org.). História da América Latina - Vol. VII: A América Latina após 1930. Estado e Política. Tradução de Antonio de Pádua Danesi. São Paulo: Edusp, 2009, p. 174; ROUQUIÉ, Alain; SUFFERN, Stephen. Os militares na política 
DIREITOS POLÍTICOS DE ESTRANGEIROS RESIDENTES NO BRASIL: CRITICA DOS PROJETOS LEGISLATIVOS NO CONTEXTO MIGRATÓRIO DA AMÉRICA LATINA

Tais fatos são constantemente evidenciados pelos episódios nos quais forças políticas conservadora ingressaram com ações judiciais contestando a validade de leis que, por exemplo, criaram cotas para negros e indígenas em universidades ${ }^{45}$ e no serviço público, que aumentaram as proteções para as mulheres em casos de violência doméstica ${ }^{46}$, ou ainda, na resistência parlamentar de se criminalizar a homofobia ou de ser regulamentar o direito de propriedade à terra dos quilombolas, estabelecido na Constituição Federal de 1988, matéria que também foi judicializada por partidos conservadores perante o Supremo Tribunal Federal (STF).

Em que pese o deslocamento de estrangeiros nos dois últimos séculos ter dado origem a grande parte a população brasileira, por meio de contingentes significativos oriundos da África (originalmente por meio do deslocamento forçado da escravidão ou, mais recentemente, por meio da imigração), Europa (especialmente italianos, espanhóis, portugueses e alemães) e Ásia (especialmente japoneses e mais recentemente chineses e coreanos), há no Brasil uma espécie seletividade no tratamento interpessoal, que inclui notório preconceito mais acentuado aos nacionais oriundos de: (i) países latino-americanos etnicamente mais identificados com indígenas ${ }^{47}$; (ii) negros oriundos da América Latina (especialmente Haiti) ou África; (iii) asiáticos chineses ou coreanos.

De outra parte, o branco europeu não apenas possui uma imunidade, mas é exaltado em suas supostas virtudes. Em suma, a apesar da constituição plural, não há uniformidade no

latino-americana após 1930. In: BETHELL, Leslie (Org.). História da América Latina - Vol. VII: A América Latina após 1930. Estado e Política. Tradução de Antonio de Pádua Danesi. São Paulo: Edusp, 2009, p. 213. 45 SUPREMO TRIBUNAL FEDERAL. STF julga constitucional política de cotas na UnB. Disponível em: http: / / www.stf.jus.br/portal/cms/verNoticiaDetalhe.asp?idConteudo=206042. Acesso em: 09 abr. 2017.

46 SUPREMO TRIBUNAL FEDERAL. ADC 19: dispositivos da Lei Maria da Penha são constitucionais. Disponível em: http://www.stf.jus.br/portal/cms/verNoticiaDetalhe.asp?idConteudo=199845. Acesso em: 09 abr. 2017.

47 “A partir disso, apresento três pressuposições para a análise de discriminação. A primeira é de que ela apresenta resultados diferentes entre os grupos de imigrantes: positiva em alguns casos e negativa em outros. A segunda é de que a discriminação negativa é sofrida por bolivianos, paraguaios, peruanos e uruguaios e a positiva por argentinos, chilenos, coreanos e chineses. A terceira é de que a discriminação negativa aumenta e a positiva reduz, quando o grupo de referência são os nativos migrantes. A primeira e a última são confirmadas. A segunda é rejeitada, uma vez que, entre os chilenos e os coreanos, não verifico a discriminação positiva frente os brasileiros migrantes; além disso, os chineses apresentam uma possível discriminação negativa, quando comparados aos brasileiros em geral". (VILELA, Elaine Meire. Desigualdade e discriminação de imigrantes internacionais no mercado de trabalho brasileiro. Dados, Rio de Janeiro, v. 54, n. 1, p. 89-128, 2011. Disponível em: http://www.scielo.br/scielo.php?script=sci_arttext\&pid=S0011-52582011000100003\&lng=en\&nrm=iso. Acesso em 10 Abr. 2017). 
ISSN 1981-3694

(DOI): $10.5902 / 1981369430115$

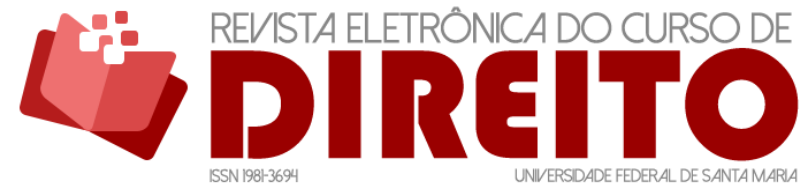

DIREITOS POLÍTICOS DE ESTRANGEIROS RESIDENTES NO BRASIL: CRITICA DOS PROJETOS LEGISLATIVOS NO CONTEXTO MIGRATÓRIO DA AMÉRICA LATINA

LUIZ ISMAEL PEREIRA CAMILO ONODA CALDAS

tratamento e, portanto, manifestações de preconceito e tratamento diferenciado no campo econômico são recorrentes contra grupos étnicos específicos ${ }^{48}$.

O segundo obstáculo é a ausência de fortes lideranças e movimentos políticos organizados por estrangeiros voltados a ampliar sua participação política no Brasil, seja como eleitores ou como candidatos. Justamente, por estarem desprovidos de direitos políticos, não possuem mecanismos formais para serem representados e perdem capacidade de pressionar politicamente os candidatos e representantes políticos existentes.

Ademais, conforme apontamos anteriormente, o Estatuto do Estrangeiro, revogado em maio de 2017, colocava em risco os estrangeiros que eventualmente promovessem ações ou criassem organizações políticas com esse objetivo, uma vez que poderiam, eventualmente, terem suas atividades tipificadas como crime, recebendo como sanção detenção e expulsão. Com o advento da nova legislação, em que pese os estrangeiros “irregulares" permanecerem intimidados pelas leis, há um potencial de que ações organizadas venham a surgir no médio prazo.

O terceiro obstáculo consiste na tímida integração do Brasil aos demais países e blocos regionais existentes na América Latina. Apesar de compor o Mercosul, há uma nítida tensão política interna no Brasil entre os que defendem uma integração latino-americana e os aqueles que se alinham com os interesses do capital internacional do centro do capitalismo. Deste modo, defendem um afastamento na relação com a latino-américa e uma aproximação com outros países, especialmente os Estados Unidos da América.

O cenário político após a deposição da presidente Dilma Rousseff fez emergir forças políticas ainda menos comprometidas em integrar o Brasil com os demais países da América Latina e o estado de crise política e institucional não favorece avanços neste sentido. Com isso, em que pese alguns países da América Latina e do Mercosul terem reconhecidos direitos políticos aos estrangeiros residentes em seu país, o Brasil, ao não caminhar para uma integração mais consistente e orgânica com a latino-américa, não se sente compelido a estabelecer regras paritárias, seja para garantir direitos específicos para os latino-americanos, seja para adotar leis voltadas a ampliação dos direitos políticos dos imigrantes em geral (o que favoreceria, em primeiro lugar, os habitantes da América Latina, face a predominância migratória dos países dessa região, conforme expusemos anteriormente).

\footnotetext{
${ }^{48}$ CAMPOS, Gustavo Barretos de. Dois séculos de imigração no Brasil: A construção da imagem e papel social dos estrangeiros pela imprensa entre 1808 e 2015. Tese (Doutorado em Comunicação e Cultura), Rio de Janeiro, Universidade Federal do Rio de Janeiro, 2015. Disponível em: http://midiacidada.org/img/tese_final_GBC_final.pdf. Acesso em: 09 abr. 2017.
} 


\section{CONCLUSÃO}

O fluxo de imigrantes da América Latina para o Brasil se desenvolve de forma crescente na atualidade e exige respostas políticas com a finalidade de integrar o estrangeiro à sociedade com a qual passa conviver.

As pesquisas sobre as recentes imigrações no Brasil e no mundo devem considerar o declínio do regime de acumulação fordista no capitalismo e a ascensão do modelo pós-fordista marcado pela superexploração do trabalho, diminuição de direitos sociais, precarização das condições de trabalho, criminalização e marginalização de grupos sociais, fenômenos estes que se interligam com o fluxo e a presença de imigrantes integrados economicamente com nações estrangeiras, mas jurídica e politicamente excluídos.

A nova Lei da Migração brasileira, mesmo com suas limitações, trouxe avanços substanciais, diminuindo limitações aos direitos políticos dos estrangeiros, sobretudo o de se engajarem em movimentos e manifestações políticas. Contudo, no nível constitucional permanece a restrição do direito ao voto ao estrangeiro residente no país.

Após a redemocratização no Brasil, diversas propostas de emenda à constituição (PEC) foram apresentadas com a finalidade de ampliar os direitos políticos de estrangeiros em território brasileiro. Alguns projetos tramitam atualmente na Câmara dos Deputados e no Senado Federal.

As propostas em curso divergem entre si em vários aspectos: condições para o exercício do direito ao voto (existência ou não de período mínimo de residência e sua duração); extensão do direito (votar e ser votado ou apenas votar); abrangência do direito (todas as esferas do Estado ou apenas a esfera municipal).

Há um potencial de avanço em relação aos direitos políticos do estrangeiro no Brasil, contudo, além do viés restritivo das propostas atualmente em curso, há obstáculos políticos para sua aprovação, especialmente: (i) preconceito contra imigrantes oriundos de países da América Latina e presença de grupos de extrema direita com discurso e ações de intolerância; (ii) ausência de movimentos e lideranças políticas de destaque no cenário nacional voltadas a defesa dos direitos políticos de estrangeiros; (iii) dificuldades de integração do Brasil com demais países da América Latina, sobretudo dentro do contexto brasileiro de crise política e institucional.

A inexistência de direito ao voto para estrangeiros no Brasil cria um círculo vicioso: a ausência de direito ao voto diminui a capacidade dos estrangeiros em pressionar o Poder 
DIREITOS POLÍTICOS DE ESTRANGEIROS RESIDENTES NO BRASIL: CRITICA DOS PROJETOS LEGISLATIVOS NO CONTEXTO MIGRATÓRIO DA AMÉRICA LATINA

LUIZ ISMAEL PEREIRA CAMILO ONODA CALDAS

Legislativo a criar leis voltadas para ampliar seus direitos políticos e, assim, dar a eles um poder político maior. Permanece no Brasil um descompasso em relação a outros países da América Latina e do mundo no que diz respeito ao direito de voto dos estrangeiros o que evidencia a existência de um viés formalmente menos democrático no Brasil em relação a esses outros países.

\section{REFERÊNCIAS}

ALMEIDA, Silvio Luiz de. Racismo. Enciclopédia Jurídica. Disponível em:

https://enciclopediajuridica.pucsp.br/verbete/92/edicao-1/racismo. Acesso em: 09 abr. 2017.

ARANTES, José Tadeu. Imigrantes: as brechas para o acolhimento. Disponível em:

http://agencia.fapesp.br/imigrantes_as_brechas_para_o_acolhimento/21466/. Acesso em: 09 abr. 2017.

ASSOCIAÇÃO BRASILEIRA DE ANTROPOLOGIA. Análise crítica sobre o PL 2516/14. Disponível: https://jornalggn.com.br/sites/default/files/documentos/analise_critica_do_pl2516_comite_mi gracoes_e_deslocamentos_da_aba1_co_pia_1.pdf. Acesso em: 09 abr. 2017.

BERCOVICI, Gilberto. 0 estado de exceção econômico e a periferia do capitalismo. Pensar, Fortaleza, v. 11, fev. 2006.

BOBBIO, Norberto. Existe uma ciência política marxista? In: ARAÚJO, Braz José; FIGUEIREDO, Eurico de Lima (org.). 0 marxismo e o Estado. Trad. Federica L. Boccardo e Rennée Levie. Rio de Janeiro: Graal, 1979.

BRASIL. Câmara dos Deputados. Proposta de Emenda Constitucional n 61/1999. Dá nova redação aos $\S \S 2^{\circ}$ e $3^{\circ}$ do artigo 14 da Constituição Federal (concede cidadania ativa e passiva ao estrangeiro, restrita a nível municipal). Disponível em:

https://www25.senado.leg.br/web/atividade/materias/-/materia/40987. Acesso em $10 \mathrm{abr}$. 2017.

BRASIL. Câmara dos Deputados. Proposta de Emenda Constitucional $n^{\circ} 347 / 2013$. Permite que os estrangeiros residentes em território brasileiro por mais de quatro anos e legalmente regularizados alistem-se como eleitores. Disponível em:

http: //www.camara.gov.br/proposicoesWeb/fichadetramitacao?idProposicao=599448. Acesso em 10 abr. 2017.

BRASIL. Código Civil, Lei federal $n^{\circ} 10.406$, de 10 de janeiro de 2002. Disponível em:

http://www.planalto.gov.br/ccivil_03/_ato2015-2018/2017/lei/L13445.htm Acesso em: 10 abr. 2017.

BRASIL. Estatuto do estrangeiro, Lei federal $\mathrm{n}^{\circ}$ 6.815, de 19 de agosto de 1980. Disponível em: http: //www.planalto.gov.br/ccivil_03/leis/L6815.htm. Acesso em: 10 abr. 2017. 
DIREITOS POLÍTICOS DE ESTRANGEIROS RESIDENTES NO BRASIL: CRITICA DOS PROJETOS LEGISLATIVOS NO CONTEXTO MIGRATÓRIO DA AMÉRICA LATINA

BRASIL. Lei federal $n^{\circ}$ 7.716, 5 de janeiro de 1989. Define os crimes resultantes de preconceito de raça ou de cor. Disponível em: http://www.planalto.gov.br/ccivil_03/leis/L7716.htm. Acesso em: 10 abr. 2017.

CAMPOS, Gustavo Barretos de. Dois séculos de imigração no Brasil: A construção da imagem e papel social dos estrangeiros pela imprensa entre 1808 e 2015. Tese (Doutorado em Comunicação e Cultura), Rio de Janeiro, Universidade Federal do Rio de Janeiro, 2015. Disponível em: http://midiacidada.org/img/tese_final_GBC_final.pdf. Acesso em: 09 abr. 2017.

FEDERICO, Vitor. Bolsonaro vê imigrantes como "ameaça" e chama refugiados de "a escória do mundo". Disponível em: http://www.jornalopcao.com.br/ultimas-noticias/bolsonaro-veimigrantes-como-ameaca-e-chama-refugiados-de-a-escoria-do-mundo-46043/. Acesso em: 09 abr. 2017.

FILGUEIRAS, Isabel. Movimento da extrema direita pede que Temer vete nova lei. Disponível em: http://www.opovo.com.br/jornal/politica/2017/04/movimento-da-extrema-direita-pede-quetemer-vete-nova-lei.html. Acesso em: 09 abr. 2017.

HAUDUK, Ron; WUCKER, Michele. Immigrant Voting Rights Receive More Attention. Migration Policy Institute. Disponível em: http://www.migrationpolicy.org/article/immigrant-votingrights-receive-more-attention. Acesso em: 10 abr. 2017.

HERRERA FLORES, JoaquÍn. A (re)invenção dos direitos humanos. Florianópolis: Fundação Boiteux, 2009.

HOLLOWAY, John. Global capital and the National State. Capital \& Class, NY, New York University, 1994, 18:23, p. 31. Disponível em: http://dx.doi.org/10.1177/030981689405200103. Acesso em 30 nov. 2018.

JINKINGS, Ivana; DORIA, Kim; CLETO Murilo; SINGER, André. Por que gritamos golpe?: para entender o impeachment e a crise política no Brasil. São Paulo: Boitempo, 2016.

MASCARO, Alysson Leandro. Estado e forma política. São Paulo, Boitempo, 2013.

MINISTÉRIO DA JUSTIÇA. Brasil tem quase 9 mil refugiados de 79 nacionalidades. Disponível em: http:// www.justica.gov.br/noticias/brasil-tem-quase-9-mil-refugiados-de-79nacionalidades-1. Acesso em: 09 abr. 2017.

OLIVEIRA, André de. Xenofobia, bomba e detenções: 24 horas tensas após ato contra lei de migração. Disponível em:

http://brasil.elpais.com/brasil/2017/05/04/politica/1493859671_902222.html. Acesso em: 09 abr. 2017.

PORTAL BRASIL. Número de trabalhadores imigrantes no País cresceu 131\%. Disponível em: http://www.brasil.gov.br/economia-e-emprego/2016/12/numero-de-trabalhadores-imigrantesno-pais-cresceu-131. Acesso em: 09 abr. 2017.

${ }^{1}$ SILVA, Alexandre Pereira da. O novo pleito brasileiro no mar: a plataforma continental estendida e o projeto Amazônia Azul. Revista Brasileira de Política Internacional, v. 56, n. 1, 
2013, p. 117. Disponível em: http://dx.doi.org/10.1590/S0034-73292013000100006. Acesso em 30 nov. 2018.

SUPREMO TRIBUNAL FEDERAL. ADC 19: dispositivos da Lei Maria da Penha são constitucionais. Disponível em: http: //www.stf.jus.br/portal/cms/verNoticiaDetalhe.asp?idConteudo=199845. Acesso em: 09 abr. 2017.

URUGUAI. Constitución de la republica, de 16 de diciembre de 1951. Disponível em: http://www.pgdlisboa.pt/leis/lei_mostra_articulado.php?nid=2160\&tabela=leis. Acesso em: 01 abr 2017

VELASCO, Clara; MANTOVANI, Flávia. Em 10 anos, número de imigrantes aumenta $160 \%$ no Brasil, diz PF: Só em 2015, quase 120 mil estrangeiros deram entrada no país. Haitianos lideram o ranking atual, seguidos pelos bolivianos. Disponível em:

http://g1.globo.com/mundo/noticia/2016/06/em-10-anos-numero-de-imigrantes-aumenta-160no-brasil-diz-pf.html. Acesso em 06 abr. 2017.

WOLKMER, Maria de Fátima S. Cidadania cosmopolita, ética intercultural e globalização neoliberal. Revista Sequência. $N^{\circ} 46$, jul. 2013, p. 37. Disponível em: https://periodicos.ufsc.br/index.php/sequencia/article/view/15290. Acesso em: 30 ago. 2018.

\section{COMO FAZER A REFERÊNCIA DO ARTIGO (ABNT):}

PEREIRA, Luiz Ismael; CALDAS, Camilo Onoda. Direitos políticos de estrangeiros residentes no Brasil: crítica dos projetos legislativos no contexto migratório da América Latina. Revista Eletrônica do Curso de Direito da UFSM, Santa Maria, RS, v. 13, n. 3, p. 1043-1068, dez. 2018. ISSN 1981-3694. Disponível em: < https: //periodicos.ufsm.br/revistadireito/article/view/30115 >. Acesso em: dia mês. ano. doi: http://dx.doi.org/10.5902/1981369430115 . 